УДК 811.111'367:81'22+82-1(73)

DOI https://doi.org/10.32447/2663-340X-2019-5-17

\title{
ANCIENT POETICS AS A PRECURSOR OF COGNITIVE STUDIES OF POETIC SYNTAX
}

\author{
Mosiichuk Antonina Viktorivna \\ Candidate of Philological Sciences, \\ Associate Professor at the Department of English Philology, \\ Vinnytsia Mykhailo Kotsiubynskyi State Pedagogical University \\ Str. Ostroz'kogo, 32, Vinnytsia, Ukraine \\ Grachova Iryna Yevgeniivna \\ Candidate of Philological Sciences, \\ Associate Professor at the Department of English Philology, \\ Vinnytsia Mykhailo Kotsiubynskyi State Pedagogical University \\ Str. Ostroz'kogo, 32, Vinnytsia, Ukraine
}

\begin{abstract}
The article traces the main vectors of syntactic studies in ancient poetics in a bid to prove that the latter has laid a solid foundation for the linguistic and cognitive analysis of the syntactic organization of literary texts in current cognitive poetics and cognitive linguistics. The conducted research has revealed that the theoretical and methodological framework of cognitive poetics has adopted a range of terms, methods, and approaches to the analysis of syntactic constructions, which appeared in ancient rhetoric and stylistics. In particular, the present study refers to the prominent philosophers and rhetoricians of the antique period whose works introduced the key notions of poetic syntax such as figure, schema, construction, iconicity, and others linking them to their current interpretation and usage in modern cognitive poetic studies. The article thus claims that present-day linguistic and cognitive analysis of poetic syntax dates back to ancient poetics and considerably overlaps with the classic antique tradition of examining syntax. In particular, the research has shown that ancient scholars underlined the significant role of syntactical means in actualizing cognitive categories making first attempts to study syntax with regard to human cognitive activity, which is reflected in the analysis of syntactic constructions as pairings of form and conceptual content within both scientific schools. The research thus attempts to show that current cognitive studies of poetic syntax resonate with the ancient interpretation of syntactic organization of poetry texts, which allows the proponents of cognitive poetics to effectively integrate the achievements of the antique school into the present-day studies of poetic syntax.
\end{abstract}

Key words: ancient poetics, cognitive poetics, poetry text, poetic syntax, figure of speech, image-schema, construction.

Introduction. During the antique epoch, people made the first attempts to understand the world in the diversity and complexity of its manifestations by expressing their thoughts and feelings through language units. The rapid development of art and science stipulated the need for effective means of communication $[4,53-54 ; 1320-21 ; 14,28]$, which would allow organizing utterances and texts. Hence, grammar, and syntax in particular, as a study of composing sentences, took a central place in ancient poetics [13, 26-29, 31-32].

The topicality of analyzing the study of poetic syntax in ancient poetics stems from the fact that present-day cognitive poetic analysis of syntactic constructions has a close connection with the theoretical and methodological framework of ancient poetics whereby many of the terms and principles of examining syntactic units have been adopted and expanded in further cognitive studies.

(C) Mosiichuk A. V., Grachova I. Ye. Ancient poetics as a precursor of cognitive studies of poetic syntax
Analysis of recent researches and publications. In their works, the representatives of current cognitive linguistics (M. Johnson, G. Lakoff, M. Turner) [15; 16; 19] often turn to the achievements of ancient poetics as a field where the prototypes of many cognitive terms such as image-schema, iconicity, conceptual pattern, etc. emerged. Thus, in his work "Figure", M. Turner emphasizes that 'schema' (Latin translation - figure) (the central notion of presentday cognitive linguistics) used to be a technical term of Greek rhetoric defined as a pairing of form and meaning, or conceptual pattern $[19,45]$. Further, the prototype of the popular cognitive term 'image-schema' introduced by M. Johnson [15] also appeared in ancient rhetoric alongside with the idea that people experience syntactic forms imageschematically $[19,49]$. Notably, the mechanism of matching the form's image schema to the meaning's image schema - known in current linguistic tradition as 'iconicity of form' - was also first described by ancient rhetoricians $[19,49]$. 
The purpose of the article is to reveal the points of intersection and resonance between the study of poetic syntax in ancient and cognitive poetics in a bid to prove that ancient poetics has laid a solid foundation for the cognitive research of poetic syntax. The tasks of the paper are to give a short overview of the main directions of poetic syntactic studies in ancient poetics, to highlight the notions and terms, which have been adopted by cognitive poetics, and to reveal how the achievements of both schools can be effectively integrated into the present-day research of poetic syntax.

The methods of the research encompass general scientific methods, including induction, deduction, analysis, and synthesis. The linguocognitive analysis of the syntactic organization of poetry abstracts necessitated the application of the methods of conceptual and contextual-interpretative analyses.

Results. Analysis of early syntactic studies in ancient Greek rhetoric shows that the latter has given birth to a number of terms of cognitive linguistics and cognitive poetics. To begin, the philosophers and rhetoricians of the ancient period emphasized the role of grammatical means in objectifying thoughts through words. The materialistic philosophy of atomism gave rise to an ancient doctrine of language, which set the foundation for the subsequent formation of the grammar theory [13, 20-21]. Thus, in his works, Democritus projected the philosophical concept of the universe structure onto linguistic material deducing the form of the word ('name') from letters by analogy with the universe structured by atoms. Proceeding from this definition of the word, the sentence, as a unit of higher order, was defined as a link of words, or 'names'. Accordingly, the correlation between the universe and linguistic units was presented as follows: atom $\rightarrow$ thing $\rightarrow$ universe $=$ letter $\rightarrow$ syllable $\rightarrow$ name $=$ name $\rightarrow$ phrase $\rightarrow$ sentence [7,37].

Notably, it was during the antique period that philosophers and rhetoricians went far beyond exploring the structural potential of syntactic units. In fact, as cognitive scientist M. Turner writes, "classical rhetoricians had anticipated some of the most influential discoveries about the nature of form-meaning pairs" [19, 45-46], the most important of which was that "linguistic patterns prototypically have conceptual anchors" [ibid., 47]. This approach resonates with present-day cognitive syntactic studies which focus on constructions as pairings of form and content whereby the latter is mapped onto the former [17].

To achieve accuracy and clarity of verbal expression, ancient writers and poets put special emphasis on the role of word order and cohesion, which was achieved chiefly by using conjunctions. Based on the relations set between the parts of the sentence, conjunctions fell into linking, dividing, replenishing, causative, and concluding [9, 145]. Conversely, the absence of conjunctions and interrupted speech were viewed as factors contributing to obscurity and ambiguity of sentences $[6,205]$. In this regard, solecism, i.e. the absence of agreement between the preceding and the following words, was considered an obstacle that might prevent orators from achieving purity of speech [11, 203].

Syntax as a study of ordering words and their agreement within sentences and texts formed a separate area of grammar during the ancient period whereby syntactic studies were realized with regard to the semantic compatibility of parts of speech and grammatical categories [13, 28-29, 32]. The first attempts to describe the syntactic dimension of literary language were made by studying phrases and compatibility of language units with a focus on word order, period, and rhythm as well as figures of speech [3, 223-224].

The rapid development of rhetoric, the science of oratory, soon resulted in a clear distinction between prose and poetry. The latter was defined as metric and rhythmic speech avoiding dullness through linguistic enrichment $[10,201]$. Correspondingly, it was necessary to differentiate between the means of prose and the means of poetic speech. In this regard, meter, or poetic rhythmic structure, was recognized as a specific feature of poetry $[2,193]$. The primary focus of ancient orators was on effective means of artistic expression. Among the methods, which could help turn a usual statement into a more powerful one, figures of speech took the main place. The term 'figure' (Lat. figura - outline, appearance), borrowed by the ancient rhetoric from the art of dance, was first used by Anaximenes from Lampsak [3, 223]. Ancient rhetoricians viewed figures as syntactic means based on syntagmatic relations, whose specific feature was to break stable syntactic models. In this regard, violation of word order played a special role in forming figures [5, 206-207]. The most accurate definition of that period was the definition of the figure as "conscious thought deviation from an ordinary and simple form of expression" for the sake of a greater poetic effect and eloquence; "revitalization of the speech form through art" [8, 276]. The use of figures of speech was aimed at achieving conciseness and clarity of statements and was chiefly justified by the orator's desire to make the speech beautiful, the reason why figures are referred to a separate section of the ancient rhetoric 'ornatus' (decoration).

Gradually, the hierarchy of the figures of speech was expanded and detailed. Thus, the writers of the $4^{\text {th }}$ century mentioned only three figures: antithesis, assonance of columns, and parisosis, which are based on opposition, similarity, and equality respectively $[1,183 ; 2,195]$. In the $1^{\text {st }}$ century, a complete classification of figures of speech appeared. The most detailed was the division of figures into the following groups: 1) figures formed by adding parts of the sentence (e.g., anaphora, asyndeton, and polysyndeton) $[8,284 ; 11,281,284]$; 2) figures constructed by reducing the elements of the sentence (e.g., zeugma, reduction) $[8,28 ; 11,286] ; 3$ ) figures based on assonance (e.g., equality of columns) [ibid., 
288]; 4) figures based on the opposition of parts of the sentence (e.g., antithesis).

Notably, each figure of speech was characterized by certain syntactic and semantic relations. Some philosophers of classical antiquity already viewed figures as anchored in conceptual patterns [19, 47]. In this regard, knowing a language was equaled to knowing its schemata [ibid., 44]. Thus, for example, Aristotle analyzed asyndeton and polysyndeton as two different form-meaning pairs standing in oppositional relations. While asyndeton was viewed as partitioning (of concepts) expressed through the formal means omitting connectives, polysyndeton was defined as chunking (of concepts) actualized by means of connectives [ibid., 48]. In this regard, the emphasis was put on learning a range of schemes as effective tools for making one's speech eloquent and powerful. Grammar, in its turn, was considered to consist of form-meaning pairs while its main goal was defined as conveying the meaning in the corresponding form. The opinion that utterances may have image-schematic structure and the image-schema of meaning can be mirrored in its form was first expressed by Longinus and Demetrius [idid., 50].

At present, some of the above-mentioned ideas can be found in cognitive studies of poetic syntax where meaning is chiefly viewed as embodied, based on common human bodily and sensory experience represented by schematic patterns known as imageschemas. As people understand the surrounding world as structured by discrete objects [15, 122], cognitive linguists and poeticians interpret syntactic constructions in terms of the image-schema OBJECT whose conceptual features are existence in space and ability to interact with other objects. The structure of the syntactic construction can be interpreted through the image-schema PART-WHOLE whose conceptual features are configuration (mutual location of parts), integrity, unity [17, 135]. Thus, for example, a sentence is understood as WHOLE whose elements (words, word-combinations, or clauses) are PARTS having certain CONFIGURATION. The configuration of WHOLE is not arbitrary, it is based on the image-schema LINEAR ORDER, whose conceptual features are horizontal extension and succession [16, 126; 17, 135]. Hence, as spatial image-schemas are grounded in human pre-conceptual experience, readers understand the syntactic meaning of constructions of a poetic text in general, schematic features. For example, in the abstract of D. Rampspeck's poem "The Marriage We Carried in Our Pockets": "And often we imagined that // the years were a locked door against which // we kept knocking to be admitted" (Rampspeck PO), the analyzed sentence can be interpreted in terms of the PART-WHOLE image-schema whereby the subordinate clauses are PARTS having specific CONFIGURATION determined by its syntactic organization: object clause ("that the years were a locked door") and attributive clause ("against which we kept knocking to be admitted").

The realization of the motivated connection between the form and the content of linguistic units in antique tradition also laid a foundation for the present-day studies of iconicity in language and literature [18]. While modern cognitive linguistics focuses on analyzing the iconicity of syntactic constructions, cognitive poetics aims at revealing the iconic features of the syntactic composition of the textual space (e.g., position, distribution, and length of poetic lines), different types of sentences (simple, compound, and complex), types of connection between clauses (coordination (syndetic/asyndetic) and subordination), word order, expressive means, and syntactic stylistic devices $[12,2]$. Consider the abstract from Allison Funk's poem "Spiral Woman":

Insomniac, she tosses, turns every which way until wound

in her sheets, she can't stop spinning inside

where voices entangle, one son's with another's, her father's bass,

mother's countervailing treble. Ne te dépêche pas!

(FVJ Funk)

The abstract is characterized by an iconic organization of the syntactic space whereby the text itself reminds of a spiral due to the winding graphic form created through the interplay of specific dispersion of poetic lines and complex sentences, which together convey conceptual complexity

Conclusions and research prospects. The theory of the figures of speech, which emerged in ancient poetics, revealed the structural as well as logical and semantic resources of syntactic units. The systematization of figures, proposed by the rhetorical tradition, laid the groundwork for the current classification of rhetorical figures in literary studies and syntactic expressive means and stylistic devices in stylistics. The appearance of such terms as schema and image-schema in modern cognitive linguistics can also be traced to the works of ancient philosophers and rhetoricians. Further research on the topic may relate to revealing the points of interception between cognitive poetics and formal poetics with regard to the method of deautomation, 'estrangement', and 'the device of complicated form' as the basic means of creating poetry texts.

\section{ЛІТЕРАТУРА}

1. Анаксимен. Риторика. Античные теории языка и стиля (Антология текстов). СПб. : Изд-во «Алетейя», 1996. C. 181-183.

2. Аристотель. Поэтика. Античные теории языка и стиля (Антология текстов). СПб. : Изд-во «Алетейя», 1996. C. 184-199. 
3. Галич, О. А. Теорія літератури. К.: Либідь, 2005. 488 с.

4. Гаспаров, М. Л. Античная риторика как система. Античная поэтика. Риторическая теория и литературная практика. М. : Наука, 1991. С. 53-54.

5. Гермоген. Античные теории языка и стиля (Антология текстов). СПб.: Изд-во «Алетейя», 1996. С. 206-207.

6. Деметрий. Античные теории языка и стиля (Антология текстов). СПб. : Изд-во «Алетейя», 1996. С. 205-206.

7. Демокрит и его последователи. Античные теории языка и стиля (Антология текстов). СПб. : Изд-во «Алетейя», 1996. С. 37.

8. Квинтилиан. Античные теории языка и стиля (Антология текстов). СПб. : Изд-во «Алетейя», 1996. С. 276, 286.

9. Коминиан. Античные теории языка и стиля (Антология текстов). СПб. : Изд-во «Алетейя», 1996. С. 145.

10. Посидоний (Диоген Лаэртий). Античные теории языка и стиля (Антология текстов). СПб. : Изд-во «Алетейя», 1996. С. 201.

11. Риторика к Гереннию. Античные теории языка и стиля (Антология текстов). СПб. : Изд-во «Алетейя», 1996. C. 203.

12. Стрільчук, А. В. Синтаксичні засоби вираження іконічності (на матеріалі текстів сучасної американської поезії). Проблеми семантики, прагматики та когнітивної лінгвістики : Зб. наук. праць Київського національного університету ім. Тараса Шевченка. К. : Вид-во «Логос», 2006. Вип. 10. С. 346-354.

13. Троцкий, И. Проблемы языка в античной науке. Античные теории языка и стиля (Антология текстов). СПб. : Изд-во «Алетейя», 1996. С. 9-32.

14. Grachova, I. Ye. Quantifiers of the English Language: Diachronic Aspect. Science and Education: A New Dimension, Philology. Budapest, 2016. IV (25), Issue 105. P. 28-32.

15. Johnson, M. The Body in the Mind. The Bodily Basis of Meaning, Imagination, and Reason. Chicago; L.: University of Chicago Press, 1987. 227 p.

16. Lakoff, G. Metaphors We Live By. Chicago: Chicago University Press, 1980. 242 p.

17. Langacker, R. W. Foundations of Cognitive Grammar: Theoretical Prerequisites. Stanford: Stanford University Press, 1987. V.1. $516 \mathrm{p}$.

18. Müller, W. G. The Iconic Use of Syntax in British and American Fiction. Form Miming Meaning: Iconicity in Language and Literature. Amsterdam/Philadelphia: John Benjamins Publishing Company, 1999. P. 393-408.

19. Turner, M. Figure. Figurative Language and Thought. New York: Oxford University Press, 1999. P. 44-87.

\section{ДЖЕРЕЛА ІЛЮСТРАТИВНОГО МАТЕРІАЛУ}

FVJ: FreeVerse : веб-сайт. URL: http://freeversethejournal.org/issue-29-2018-allison-funk/ (дата звернення: 04.04.2019).

PO: Poets.org : веб-сайт. URL: https://www.poets.org/poetsorg/poem/marriage-we-carried-our-pockets (дата звернення: 04.04.2019)

\section{REFERENCES}

1. Anaksimen (1996) Ritorika [Rhetoric]. Antichnye teorii yazyka i stilya (Antolohiya tekstov) [Antique theories of language and style (Anthology of texts)]. St. Petersburg: Aleteiya [in Russian].

2. Aristotel' (1996) Poetika [Poetics]. Antichnye teorii yazyka i stilya (Antolohiya tekstov) [Antique theories of language and style (Anthology of texts)]. St. Petersburg: Aleteiya [in Russian].

3. Demetriy (1996) Antichnye teorii yazyka i stilya (Antolohiya tekstov) [Antique theories of language and style (Anthology of texts)]. St. Petersburg: Aleteiya [in Russian].

4. Demokrit i eho posledovately (1996) [Democritus and His Followers]. Antichnye teorii yazyka i stilya (Antolohiya tekstov) [Antique theories of language and style (Anthology of texts)]. St. Petersburg: Aleteiya [in Russian].

5. Halych, O. A. (2005) Teoriia literatury [Theory of Literature]. Kyyiv: Lybid [in Ukrainian].

6. Hasparov, M. L. (1991) Antichnaya ritorika kak sistema [Ancient Rhetoric as a System]. Antichnaya poetika. Ritoricheskaya teoriya i literaturnaya praktika [Antique poetics. Rhetorical theory and literature practice]. Moscow: Nauka [in Russian].

7. Hermohen (1996) Antichnye teorii yazyka i stilya (Antolohiya tekstov) [Antique theories of language and style (Anthology of texts)]. St. Petersburg: Aleteiya [in Russian].

8. Grachova, I. Ye. (2016) Quantifiers of the English language: Diachronic aspect. Science and Education: A New Dimension, Philology, IV (25), Issue 105. Budapest [in English].

9. Johnson, M. (1987) The Body in the Mind. The Bodily Basis of Meaning, Imagination, and Reason. Chicago; London: University of Chicago Press [in English].

10. Kvintilian (1996) Antichnye teorii yazyka i stilya (Antolohiya tekstov) [Antique theories of language and style (Anthology of texts)]. St. Petersburg: Aleteiya [in Russian].

11. Kominian (1996) Antichnye teorii yazyka i stilya (Antolohiya tekstov) [Antique theories of language and style (Anthology of texts)]. St. Petersburg: Aleteiya [in Russian].

12. Lakoff, G., \& Johnson, M (1980). Metaphors We Live By. Chicago: Chicago University Press [in English].

13. Langacker, R. W. (1987) Foundations of Cognitive Grammar: Theoretical Prerequisites. Vol. 1. Stanford: Stanford University Press [in English]. 
14. Müller, W. G. (1999) The Iconic Use of Syntax in British and American Fiction. Form miming meaning: Iconicity in language and literature. Amsterdam/Philadelphia: John Benjamins Publishing Company [in English].

15. Posidoniy (1996) Antichnye teorii yazyka i stilya (Antolohiya tekstov) [Antique theories of language and style (Anthology of texts)]. St. Petersburg: Aleteiya [in Russian].

16. Ritorika k Herenniyu (1996) Antichnye teorii yazyka i stilya (Antolohiya tekstov) [Antique theories of language and style (Anthology of texts)]. St. Petersburg: Aleteiya [in Russian].

17. Stril'chuk, A. V. (2006) Syntaksychni zasoby vyrazhennya ikonichnosti (na materiali tekstiv suchasnoyi amerykans'koyi poeziyi) [Syntactic Means of Expressing Iconicity (Based on Texts of Contemporary American Poetry)]. Problemy semantyky, prahmatyky ta kohnityvnoyi linhvistyky: zb. nauk. prats' Kyyivs'koho natsional'noho universytetu im. Tarasa Shevchenka [Problems of semantics, pragmatics and cognitive linguistics: Collection of scientific papers Taras Shevchenko National University of Kyiv], 10, Kyyiv [in Ukrainian].

18. Trotskiy, Y. (1996) Problemi yazyka v antichnoi nauke [Language problems in ancient science]. Antichnye teorii yazyka i stilya (Antolohiya tekstov) [Antique theories of language and style (Anthology of texts)]. St. Petersburg: Aleteiya [in Russian].

19. Turner, M. (1999) Figure. Figurative Language and Thought. New York: Oxford University Press [in English].

\title{
SOURCES
}

FVJ: FreeVerse. Retrieved from http://freeversethejournal.org/issue-29-2018-allison-funk/.

PO: Poets.org. Retrieved from https://www.poets.org/poetsorg/poem/marriage-we-carried-our-pockets.

\section{АНТИЧНА ПОЕТИКА ЯК ПРОВІСНИК КОГНІТИВНИХ СТУДІЙ ПОЕТИЧНОГО СИНТАКИСУ}

\author{
Мосійчук Антоніна Вікторівна \\ кандидат філологічних наук, \\ доцент кафедри англійської філології \\ Вінницького державного педагогічного університету імені Михайла Кочюбинського \\ вул. Острозького, 32, Вінниия, Украӥна
}

Грачова Ірина Свгеніївна

кандидат філологічних наук, дочент кафедри англійської філології

Вінницького державного педагогічного університету імені Михайла Коцюбинського вул. Острозького, 32, Вінниия, Україна

\begin{abstract}
Метою статті є розгляд основних векторів синтаксичних досліджень в античній поетиці, який доводить, щчо остання заклала міџне підгрунтя для лінгвокогнітивного аналізу синтаксичної організачії літературних текстів у сучасній когнітивній поетиці та когнітивній лінгвістиці. Проведене дослідження показало, що теоретико-методологічний апарат когнітивної поетики запозичив иілу низку термінів, методів $і$ підходів до аналізу синтаксичних конструкиій, які з'явилися в античній риториці $і$ стилістиці. Дана розвідка відсилає до видатних філософів і риторів античного періоду, у чиїх творах з'явилися ключові поняття поетичного синтаксису, такі як фігура, схема, конструкиія, іконічність, щзо дозволяє простежити зв'язок із інтерпретацією та використанням цих термінів у сучасних когнітивно-поетичних студіях. У статті стверджується, щео лінгвокогнітивний аналіз поетичного синтаксису бере початок у античній поетиці і перегукується із класичною античною традицією вивчення синтаксису. Зокрема, дослідження показало, щчо античні вчені наголошували на важливій ролі синтаксичних засобів в актуалізації когнітивних категорій, таким чином зробивши перші спроби дослідити синтаксис з огляду на мисленнєву діяльність людини, щзо знайшло вираження в аналізі синтаксичних конструкиій як двосторонніх утворень форми і концептуального наповнення в обох дослідницьких напрямах. У статті здійснена спроба довести, ще сучасні лінгвокогнітивні студії поетичного синтаксису резонують із античним тлумаченням синтаксичної організації поетичних текстів, що дозволяє прибічникам когнітивної поетики ефективно інтегрувати надбання античної школи у сучасні дослідження поетичного синтаксису.

Ключові слова: антична поетика, когнітивна поетика, поетичний текст, поетичний синтаксис, фігура мовлення, образ-схема, конструкиія.
\end{abstract}

